\title{
酸化ストレスと皮膚一光老化から全身性強皮症まで
}

小川文秀，佐藤伸一

\section{Roles of oxidative stress in photoaging and the pathogenesis of systemic sclerosis}

\author{
Fumihide OGAWA and Shinichi SATO \\ Department of Dermatology, Nagasaki University Graduate School of Biomedical Sciences
}

(Received October 23, 2006)

\begin{abstract}
summary
Human skin is exposed to high amount of solar ultraviolet (UV) radiation, as well as to other environmental oxidants. Photoaging refers to the effect of long-term UV exposure and sun damage superimposed on intrinsically aged skin. The clinical photoaging features are dyspigmentation, laxity, wrinkles, and cutaneous malignancies. Most conspicuous photoaging change in dermis, which is caused by elastin materials accumulation, is termed "solar elastosis". Reactive oxygen species are known to be generated by UV radiation, and play an important role of photoaging. Although the pathogenesis of systemic sclerosis ( $\mathrm{SSc}$ ) remains unknown, oxidative stress has been suggested to contribute to clinical manifestations associated with SSc, such as vascular damage including Raynaud's phenomenon. This review focuses on recent data including our data which have demonstrated the critical role of oxidative stress in photoaging and the pathogenesis of SSc.
\end{abstract}

Key words_— Photoaging; Oxidative stress; Systemic sclerosis; methionine sulfoxide reductase (MsrA); 8-isoprostane

抄 録

我々の皮膚は常に外界からの様々な刺激にさらされている，その刺激の代表的なものとして太陽光線中の紫外線 があげられる，紫外線は皮膚癌の発生の誘因となる他に，紫外線の曝露により皮膚には光老化と称される変化が生 じてくる. 光老化の特徵的な変化として皮膚表面のびまん性の色素沈着と深い鄒があげられるが，その変化を特徵 づけるものとして皮膚真皮における solar elastosis と称される膠原線維・弾性線維の変化がある.この皮膚光老化 には紫外線による酸化ストレスが梁く関与していると考えられている，一方，酸化ストレスが関与する全身疾患の 一つとしてとして全身性強皮症（systemic sclerosis；SSc）があげられる．SSc は全身の皮膚硬化を主徵とする膠原 病であるが，レイノ一症状をはじめとする血管障害も病態形成に深く関与していると考えられている，本稿では， 酸化ストレスが皮膚に与える影響を光老化と SSc に関して我々の研究結果とこれまでの研究知見を中心に概説する.

\section{I. はじめに}

我々の皮膚は常に外界からの様々な刺激に曝され ている. 物理学的刺激, 化学的刺激, 温度変化そし て紫外線曝露などである。その刺激の一つである紫 外線曝露は皮膚癌の発生率を高める誘因として知ら れているが，同時に，皮膚の形態的変化を引き起こ す誘因ともなつている，紫外線曝露によつて特徵づ けられる皮膚形態の変化を光老化と称する．その変 化は真皮における solar elastosis と呼ばれる膠原線 維・弾性線維の変化が主体であるが，この solar elastosis の発生に活性酸素・酸化ストレスが重要な

長崎大学大学院医歯薬学総合研究科皮膚病態学分野
役割を果たしていることが明らかにされてきてい る.このような酸化ストレスに対して皮膚には抗酸 化機構が存在しその影響を最小限に抑える働きをし ている。.また，酸化ストレスは紫外線曝露のみなら ず，血管の虚血・再還流によっても発生する.

全身性強皮症（systemic sclerosis；SSc）は全身の 皮膚硬化を主徴とする膠原病であるが, SScの主要 な症状としてレイノ一症状をはじめとする血管障害 が挙げられる. SSc での血管障害による活性酸素の 発生は酸化ストレスとなり SSc の臓器病変の出現 や，SSc の病勢に影響を与えていると考えられてい る. 本総説においては，光老化における酸化ストレ スの関与と抗酸化酵素の働き，また，SScにおける 酸化ストレスの病勢・病状に対する関与を我々の研 
究を中心に現在までの報告を含めて概説したい.

\section{II. 光老化とは}

通常われわれの皮膚は加齢に伴い萎縮・菲薄化し てくる。一方，農業従事者や戸外労働者など長期間 紫外線に曝された皮膚は加齢による皮膚の萎縮性の 変化を伴わず，項部菱形皮膚と呼ばれるような深い 㱀，不規則な色素沈着，弾力性のない皮膚となって くる（図 1A）。この様な長期間紫外線に暴露され た皮膚に生じる特徵的な変化は光老化と称される.

この状態の皮膚を病理学的に検討すると表皮の肥厚 と真皮に好塩基性の均一な色調を持つ物質が認めら れ，正常な膠原線維・弾性線維の構造が消失してい るのが確認できる（図 1B）。この真皮に認められる 変化を solar elastosis と呼び，紫外線の影響により 変性した弾性線維によるものと考えられている.

加齢による老化皮膚では，表皮の萎縮，真皮の線 維芽細胞の減少とそれに伴うコラーゲン産生の減 少, 真皮のエラスチン量の低下が認められ, 弾力の ない，菲薄化した皮膚となる。一方，光老化では， 老化皮膚と比較すると表皮は肥厚し，真皮の線維芽 細胞の増加と炎症細胞浸潤の増加はあるもののコ ラーゲン量は老化と比較しさらに減少し, 真皮のエ ラスチン量の増加が起こり，最終的には solar elastosis という特徵的な病理所見をとることになる と考えられている1).

この長期間の紫外線曝露による光老化のメカニズ ムを詳細に検討するためにヘアレスマウス $(\mathrm{Skh}-1)$ にUVA を長期間照射した。その結果，照射群では ヒトの光老化と同じように深い㱀や色素沈着などが 認められた（図 2)。組織学的に検討したところ 6 週齢の比較的若いマウスと比較すると老化したマウ
スでは表皮が萎縮して菲薄化が認められるが（図 3C), UVA 照射群では非照射群と比較し，有意な 表皮の肥厚が認められ，また真皮においては線維芽 細胞の増加と炎症細胞の浸潤の増加が確認できた (図 3B). 光老化に特徵的な solar elastosis はマウス では再現しにくいとの過去の報告と一致して，この 研究の際にも明らかな solar elastosis は認められな かった. しかし, 照射群では真皮の弾性線維の量が 非照射群と比較して増加し，不規則な太さの弾性線 維の配列の乱れと弾性線維の形態異常を示す多数の 雨粒様の断面が明らかにされている（図 4)。この 表皮と真皮の紫外線による変化は以前の報告と一致 している2 4).

このように光老化により真皮の膠原線維と弾性線 維の変化が生じるが, 膠原線維の成分であるコラー ゲン, 弾性線維の成分であるエラスチンも共に真皮 の線維芽細胞から産生される. また, 光老化皮膚に

\section{Skin change of the hairless mouse (12 months)}

UVA (+)
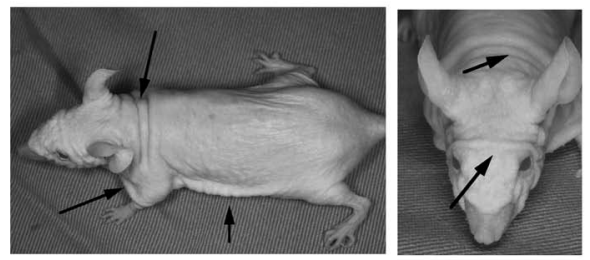

Control
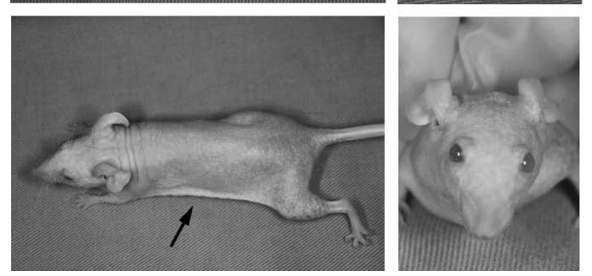

図 212 か月間UVA 照射したヘアレスマウスの皮膚変化 UVA 照射群では著明な皮膚肥厚, 色素沈着が認められ, 皮膚が全体的に粗造化している。

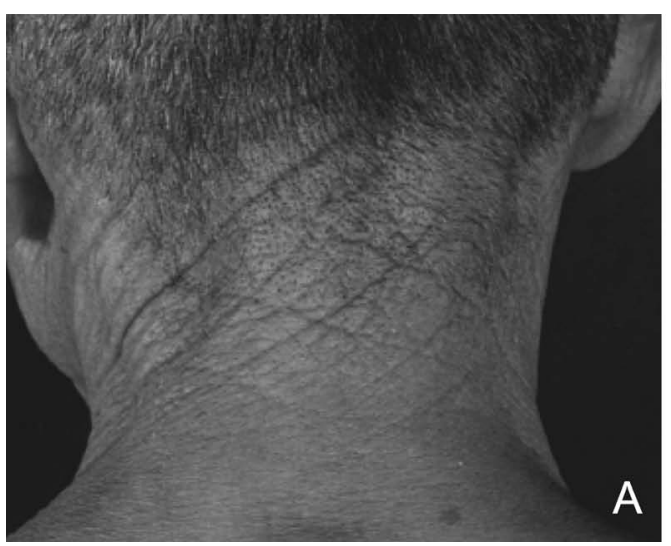

A

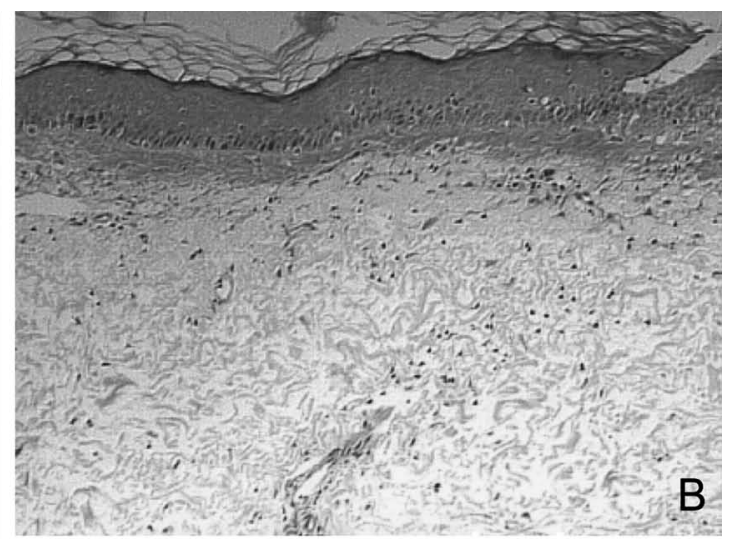

図 1

A : 長期間日光に暴露された後頸部皮膚（項部菱形皮膚） B : 典型的な紫外線曝露による表皮・真皮の变化（H＆ E 染色） 


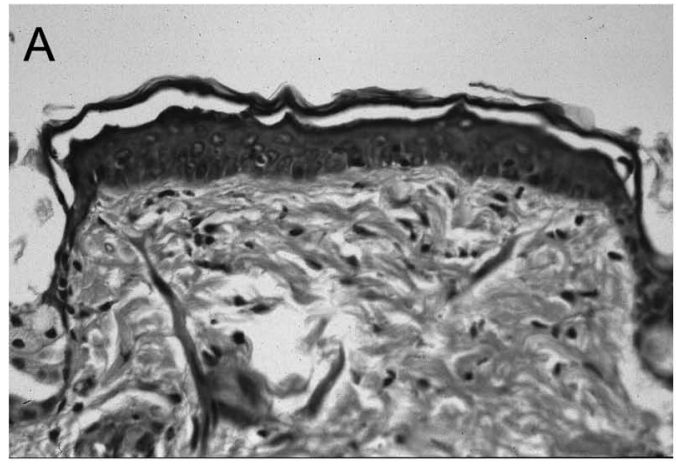

\section{Epidermal change of the hairless mouse skin}
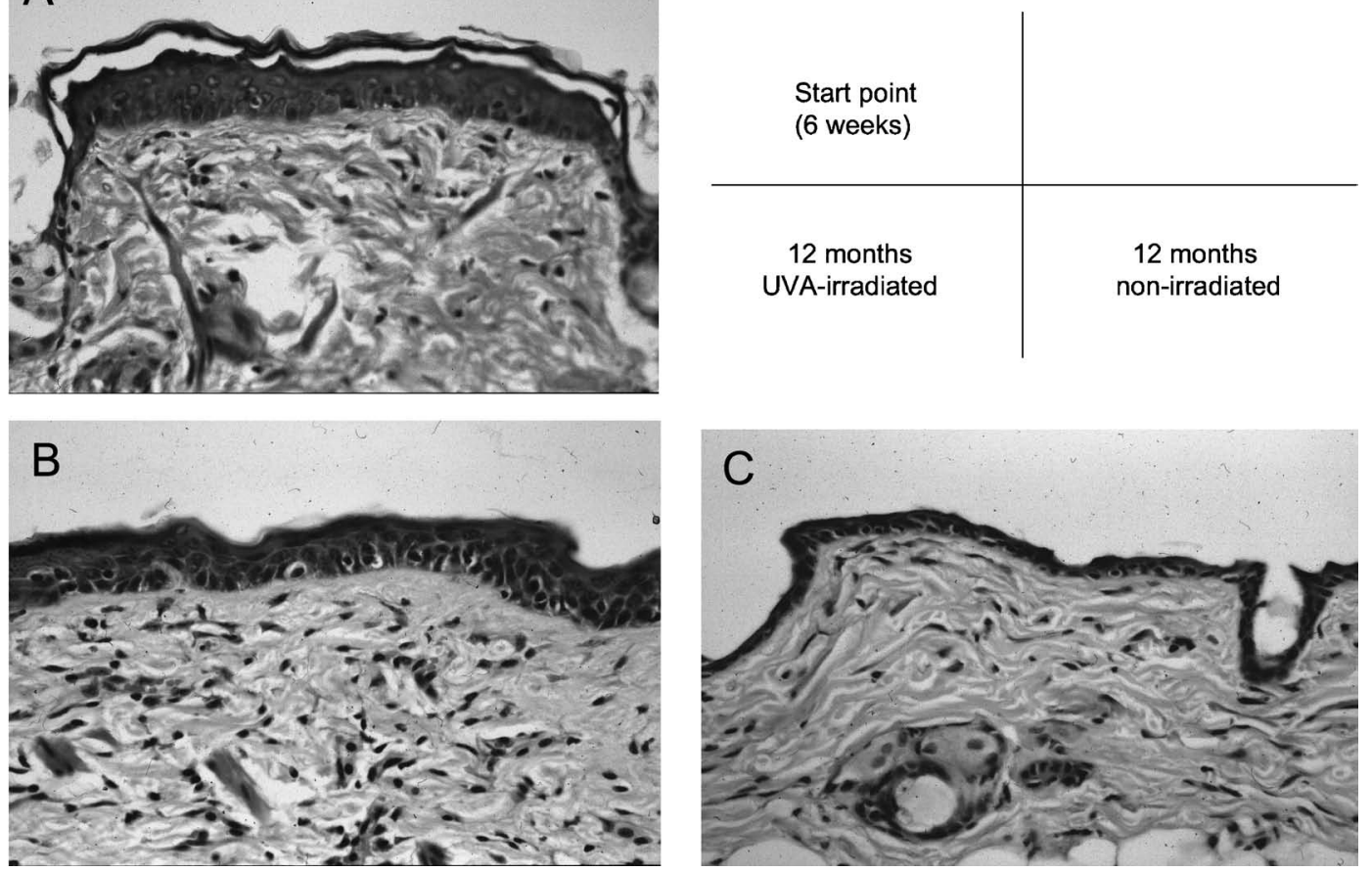

図 3 UVA 長期間照射による表皮・真皮の変化 $(\mathrm{H} \& \mathrm{E}$ 染色)

A 紫外線照射開始時の皮膚（6 週齢）：表皮は厚く，真皮の線維芽細胞も散見される B UVA12 か月照射後の皮膚：表皮は厚 く, 真皮の線維芽細胞の増加, 炎症細胞浸潤の増加が認められる C UVA 非照射群の皮膚 : 照射開始時と比較して著明な表皮の 萎縮（菲薄化）が認められ，真皮の線維芽細胞・炎症細胞浸潤も試験開始時と大きな変化は認めない

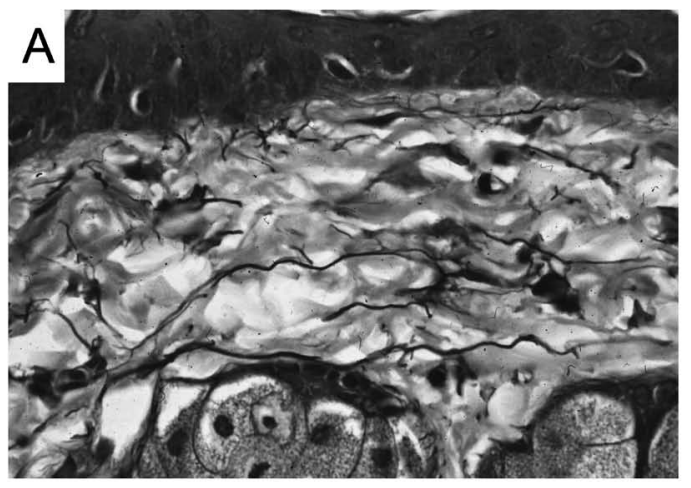

\section{Dermal elastic fiber of the hairless mouse (Weigert's resorcin-fuchsin stain)}

\begin{tabular}{c|c}
$\begin{array}{c}\text { Start point } \\
(6 \text { weeks })\end{array}$ & \\
\hline $\begin{array}{c}12 \text { months } \\
\text { UVA-irradiated }\end{array}$ & 12 months \\
& non-irradiated
\end{tabular}
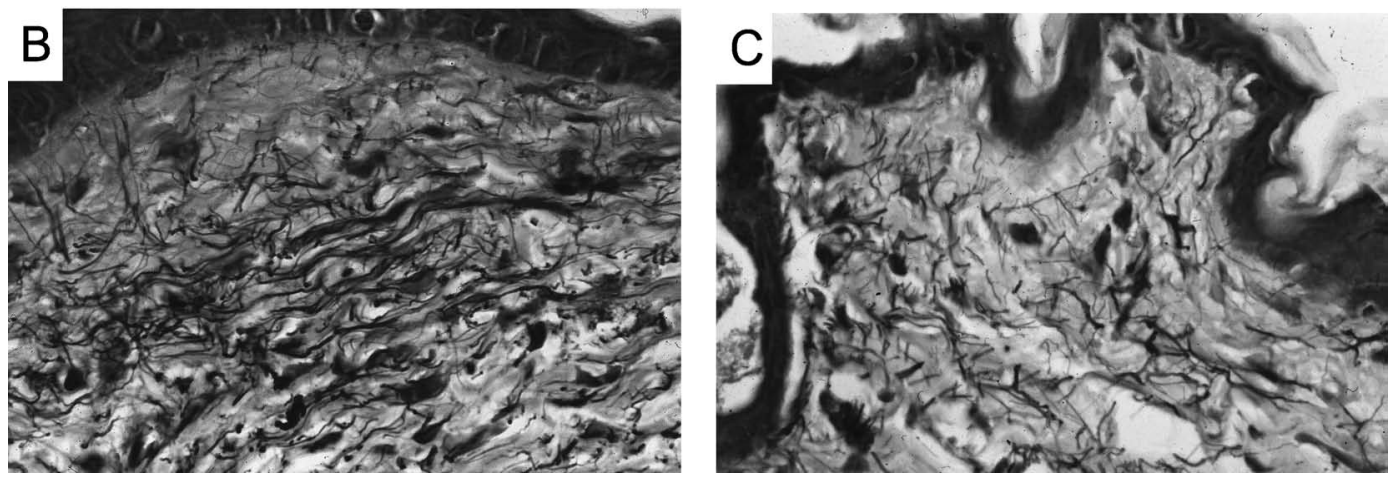

図 4 UVA 長期間照射による真皮弾性線維の変化

A 照射開始時：弾性線維の走行はなめらかであり，断裂像や配列の乱れも認めないB UVA12 か月照射後：弾性線維は増加 し，その走行は乱れ，雨粒様の弾性線維の断面が多数認められる C UVA 非照射群 : 照射群と比較して弾性線維の配列の乱れは 少ない 
おいては老化皮膚と比較してさらにコラーゲン量が 低下することより，コラーゲンの分解酵素である matrix metalloproteinase (MMP) の検討を行った. 過去に type I collagenase である MMP-1 をはじめ とする種々の MMP が光老化皮膚に重要な役割を 持つことが報告されているが5 8)，エラスチンも分 解することのできる type IV collagenase である MMP-2, MMP-9 の検討を行い, また, 光老化皮 膚では弾性線維が増加していたことより，その構成 成分であるエラスチン産生についての検討も行った.

まず，エラスチンの発現を紫外線照射マウス由来 皮膚で免疫染色にて検討した結果, 紫外線照射マウ スでは真皮線維芽細胞にエラスチンの産生の元進が 認められた．また， MMP-2の発現は変化がなかっ たものの，MMP-9 の発現がエラスチンと同様に真 皮の線維芽細胞で増加していた。ささらにUVA 照射 群, 非照射群のマウスより線維芽細胞を培養し mRNAの発現を比較した。 その結果, 紫外線照射 群マウスから培養した皮膚線維芽細胞においても MMP-9 の発現が非照射群と比較して 4 ヶ月照射後 より有意に上昇していた（図 5)。一方，MMP-2 の発現は 12 ヶ月後まで変化を認めなかった. Elastin の産生に関しては elastin の前駆物質である tropoelastin の mRNA の発現を検討したところ, 12 ケ月照射時点で UVA 照射群で tropoelastinの mRNA の発現が非照射群と比較して上昇していた.

このように光老化皮膚ではコラーゲン・エラスチ ンの分解促進とエラスチンの合成促進が同時に引き
起こされていることが示された，過去の報告でも培 養した線維芽細胞への紫外線照射または露光部皮膚 などで MMP-1, MMP-3, MMP-8, MMP-9 の有意 な上昇が認められている ${ }^{5 \sim 8)}$. 以上の結果より, 紫 外線の慢性・反復照射により膠原線維・弾性線維の の合成・分解が繰り返され, その結果, 修復が不十 分な膠原線維・弾性線維が真皮に蓄積し, 光老化の 特徵的な皮膚を形成する要因の一つとなっているこ とが考えられる。

紫外線照射により皮膚には酵素の発現を含む多様な 変化が生じるが, 紫外線による障害の約 $50 \%$ は紫 外線によって生じるフリーラジカルの影響であると 考えられている99.

\section{III. 紫外線と酸化ストレス}

UVA と UVB は hydrogen peroxide, superoxide anion, singlet oxygen などの様々な活性酸素種 (reactive oxygen species；ROS）を細胞内で発生す ることが知られている10,11)。また， ROS は細胞の DNA のみならず, 脂質やタンパクも傷害すること が明らかにされている ${ }^{12,13)}$. 紫外線により発生した ROS は細胞のレセプターやそのリガンドに影響を 与え ${ }^{14,15)}$, 表皮角化細胞や真皮線維芽細胞からの interleukin-1 (IL-1) や tumor necrosis factor-a $(\mathrm{TNF}-\alpha)$ などのサイトカイン産生を引き起こ し14), さらには転写因子に影響を与え, AP-1 や $\mathrm{NF}-\mathrm{kB}$ の活性化を引き起こし前述したような MMP の産生増加を誘導している16 19).

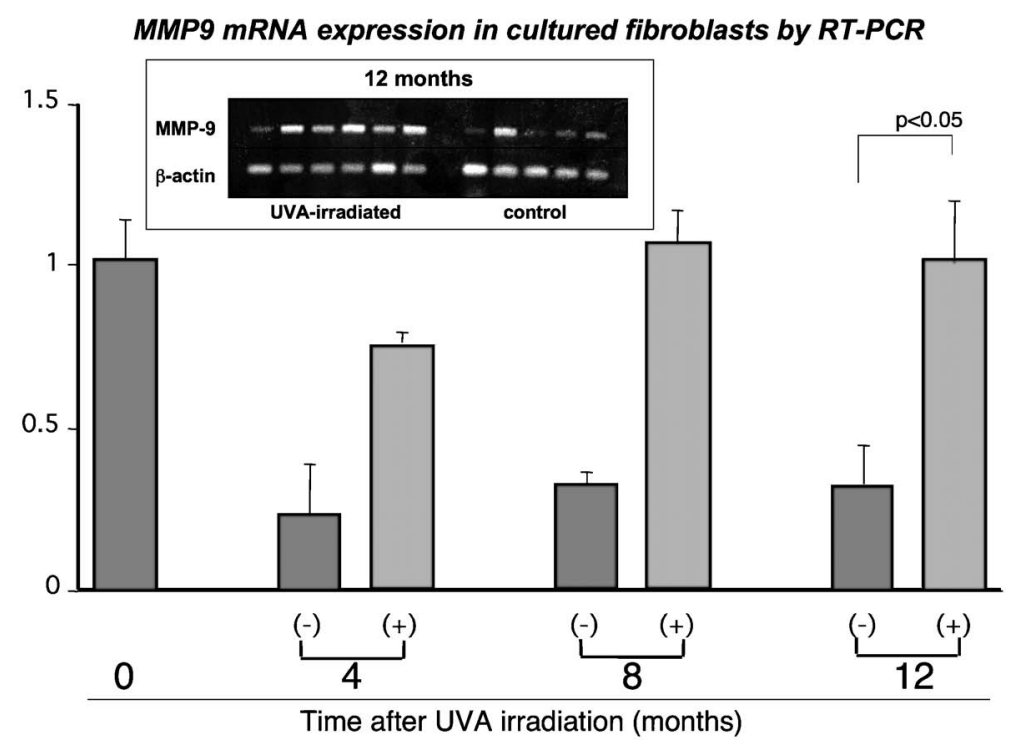

図 5 ヘアレスマウスから培養した皮膚線維芽細胞の MMP-9 mRNA の発現 UVA 照射開始 4 か月後より, MMP-9 mRNA の発現は照射群で増強している. 
この紫外線により生じた酸化ストレスの, 脂質, タンパク質, DNA への影響を緩和するために皮膚 には酵素学的あるいは非酵素学的な抗酸化システム が構築されている ${ }^{20)}$. 内因性の抗酸化物質ではビ夕

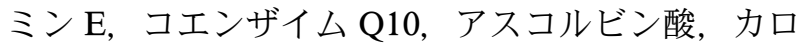
チノイドなどが挙げられ ${ }^{21)}$ ，抗酸化酵素としては superoxide dismutase (SOD), catalase, glutathione peroxidase などがある22).この抗酸化システムと光 老化の関係を酸化タンパク，抗酸化酵素の分布から 検討すると，表皮には酸化タンパクは非常に少な く, 抗酸化酵素の発現が非常に多いことが明らかに なり，それとは対照的に，真皮においては酸化夕ン パクの発現が非常に多い一方で, 抗酸化酵素の発現 が非常に低いこと明らかにされた 23).

つまり，UVA やUVBなどの紫外線に曝されや すい表皮にはその影響を排除するための抗酸化シス テムが発達しているが，真皮ではそのシステムが表 皮ほど構築されてないないため, 酸化ストレスの結 果としての酸化タンパクの蓄積が solar elastosis を 中心とした真皮の変化として表現されていると考え られた。 そこで表皮に発達している抗酸化システム にはROS を遮断（scavenge）する酵素だけでなく， 一旦形成された酸化タンパクをもとの状態にまで還 元する酵素（antioxidant repair enzyme）の存在を 予想した.

\section{IV． 抗酸化酵素 MsrA と光老化の関係}

この様な修復酵素の一つとして注目されている酵 素に methionine sulfoxide reductase (Msr) がある. この酵素は光学異性体特異的にメチオニンスルフォ キシド (methionine sulfoxide; MetO) をメチオニ ン（Met）に還元する酵素である24)．Methionine sulfoxide A （MsrA）は methionine- $S$-sulfoxide (MetSO) を, methionine sulfoxide B (MsrB) は methionine- $R$-sulfoxide (MetRO) をそれぞれ Met に還元する25).

MsrA は最初にEscherichia coli から分離され， その後, ヒトの生体内でも種々の組織にいろいろな レベルで発現していることが確認された ${ }^{26)}$. 細胞内 では MsrA は細胞質とミトコンドリアに分布して いることが明らかとなった ${ }^{27,28)}$. タンパク質中のメ チオニン残基の酸化によりタンパク質は不活性化さ れるが，MsrA はその MetSO を Met に還元し，夕 ンパク質の働きを正常化すると考えられている.

MsrA が働くためには他の抗酸化酵素と異なり金属

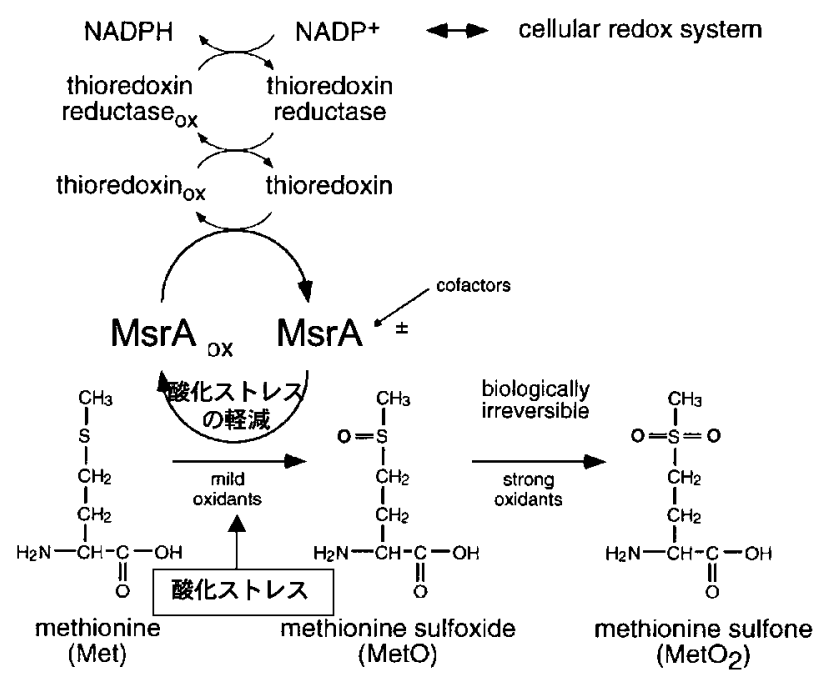

図 6 Methionine sulfoxide reductase A (MsrA) の酸化・還 元システム

や補酵素を必要としないが，酸化された MsrA を 還元するために thioredoxin や thioredoxin reductase から構成される thioredoxin regenerating system が必要となる (図 6) ${ }^{29)}$ 。この Met から MetO への酸化は翻訳後修飾として働くため, 細胞内のシ グナル伝達を変化させ ${ }^{30)}$, また, 疾患においては肺 気腫, 白内障の形成, 関節リウマチに関係があると 考えられている31,32)。また, 皮膚においては色素異 常の一つである尋常性白斑部でのメチオニン残基の 酸化が報告されている33).さらに, 酸化タンパクの 集積は細胞の老化を表すと考えられているため ${ }^{12)}$, $\mathrm{MetO}$ を還元するシステムは ROS 存在下での細胞 の生存に不可欠となる ${ }^{34)}$. 最近の研究では MsrA の ノックアウトマウスでは生存期間が短くなるのに対 し35)，MsrA を過剩発現したショウジョウバエにお いては生存期間が延長することが報告されている ${ }^{36}$. そこで, 我々はヒト皮膚における MsrA の局在と その誘導について検討を行った。慰部の皮膚に紫外 線を反復照射したところ, MsrA の発現は照射群で 有意に上昇しており，しかも，MsrA の発現は真皮 ではほとんぞ変化が認められず，表皮で増強してい ることが確認できた（図 7)。また，不死化表皮角 化細胞である $\mathrm{HaCaT}$ cell を用いて MsrA の誘導を 試みたところ, 紫外線の中でも波長の短いUVBで は MsrA の発現は減弱したものの, 波長が長く, 皮膚深部までの深達度が高いUVA で MsrA の発現 が増強された。 また，ROSの代表的な刺激である と考えられる hydrogen oxide の刺激では, 低濃度 の刺激では MsrA の発現が増強したものの, 高濃 


\section{Skin MsrA expression following repetitive solar simulated UV exposure}
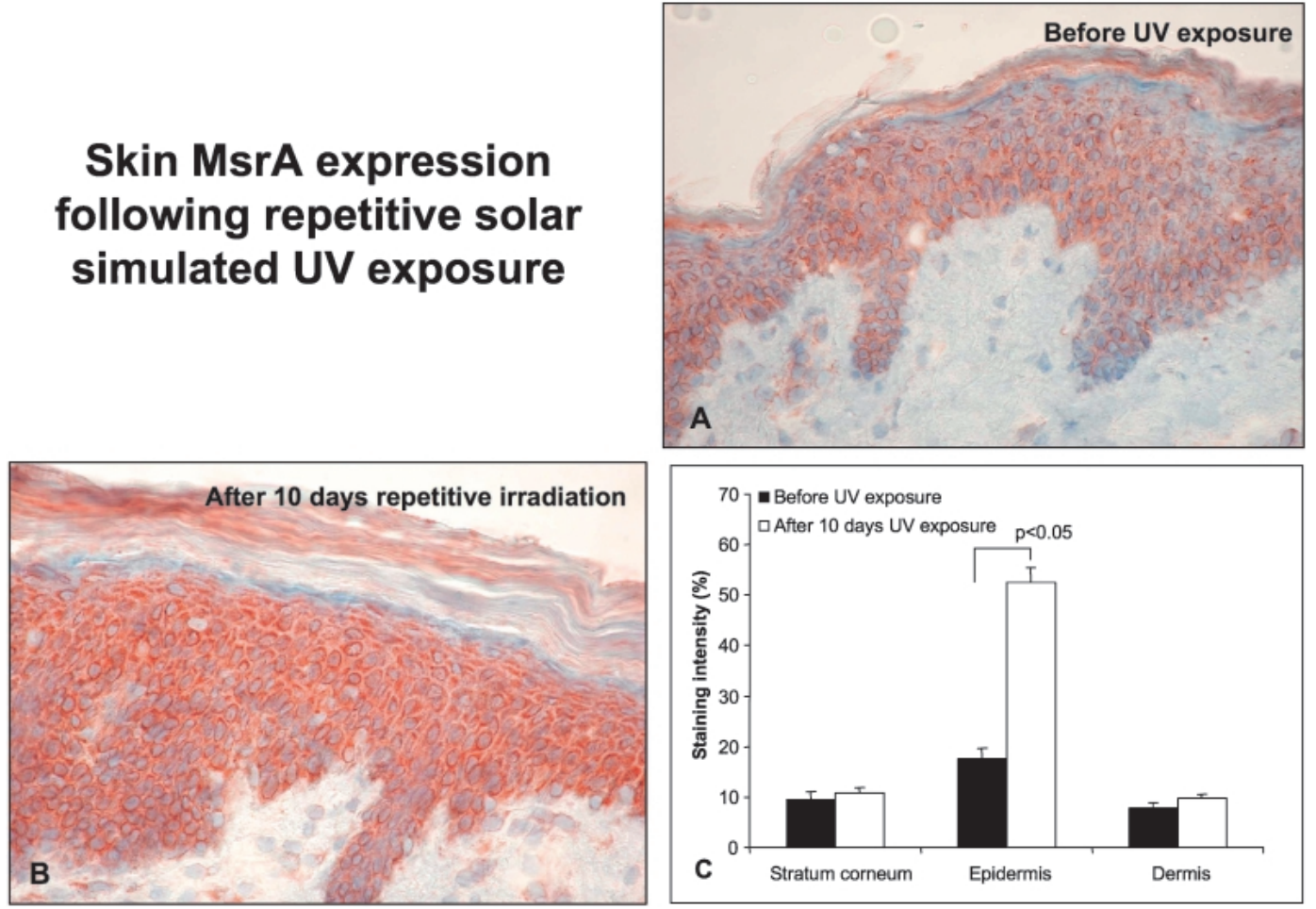

図 7 Solar simulator 刺激による MsrA 発現変化

刺激後 MsrAの発現は増加しており, 特に表皮における著しい MsrA の発現増加が認められる

度では逆に MsrA の発現が低下することが見いだ された。この実験では前項で述べたように，UVA 照射により発生した ROS が MsrA を誘導したと考 えられる。一方，UVB は MsrA を誘導せず，高用 量ではむしろ MsrA の発現低下を引き起こしたわ けだが，その原因の一つとして UVB によって引き 起こされたアポトーシスとUVBにより誘導された 細胞内の hydrogen oxide の影響が考えられる37).

UVB は DNA に直接障害を与えてアポトーシス を誘導するだけでなく, hydrogen oxide を細胞内で 発生させアポトーシスを引き起こすのである.今回 MsrA 発現が増強した hydrogen oxide の濃度はこの アポトーシスが誘導された濃度と比較し 100 分の 1 以下の低濃度であった。表皮はこのようにマイルド な酸化ストレスに対しては MsrA の発現を誘導す ることによりその影響を最小限に止めようとしてい ると考えられる。一方，真皮での MsrA の発現は 表皮と比較して非常に弱く， ヒト臀部への UV 照射 でも変化はほとんど認められなかった（図 7)。以 上のことより，真皮においては MsrA の活性が低 いために酸化ストレスが蓄積しやすく，それが最終 的には solar elastosis として光老化皮膚で表現され ている可能性が考えられた ${ }^{38)}$.

\section{V. 全身性強皮症と酸化ストレス}

SSc は線維化や血管障害が皮膚のみならず，全身 の諸藏器に出現する結合織疾患であり, 免疫異常を 背景にもつ.これまで述べたように光老化による酸 化ストレスは膠原線維の変化を誘導すると同時に, 膠原線維に変化をきたす疾患である SSc において も重要な役割を果たしていることが考えられる。酸 化ストレスはSSc の血管障害や線維化そして抗核 抗体の産生に関与している可能性が示唆されてい $3^{39)}$.

レイノー症状は血管障害, 特に血管内皮の機能不 全を臨床的に最も反映する症状であり, 血管内皮か ら産生され血管拡張作用を持つ nitric oxide（NO） の産生低下がレイノー症状出現の原因の一つと考え られている。また，レイノー症状による虚血・再潅 流はそれ自体が ROS の産生を引き起こすとされて いる。そのため多くの SSc における酸化ストレス の役割は nitric oxide (NO) に焦点が置かれ研究さ れてきた。しかしながら，SSc における NO の役割 については相反する報告が多数存在し, 一定の見解 が得られていない40). 例えば，血清中の NO が上 昇しているという報告と低下しているという報告が 存在し, また, NO の病理学的, 病因学的役割につ 
いても様々な矛盾する報告が存在する．NO は血管 拡張作用があるためSSc における末梢の虚血を改 善させるといった報告がある一方で41)，レイノー症 状の後の虚血再潅流状態で生成された NO がヒド ロキシラジカルを合成し, 組織障害に働くといつた 研究などが存在する42).

\section{VI. 酸化ストレスマーカー 8-isoprostane と SSc の病勢}

そこで SSc における酸化ストレスの関与を検討 するためにマーカーとして 8-isoprostane を用いた. 8-isoprostane はエイコサノイドの一種であり, 組 織内のリン脂質が活性酸素により酸化され生じる物 質である ${ }^{43)}$. 生化学的に安定した物質であるために 酸化ストレスを評価する有用なマーカーであると考 えられている. 実際に喫煙者 ${ }^{44)}$, 心疾患 ${ }^{45)}$, 呼吸器 疾患 ${ }^{46)}$ で正常人と比較して上昇が認められることが 報告されている.

そこで, SSc における血清中 8-isoprostane 值と その臨床的相関について検討した ${ }^{47)}$. まず SScに おける血清中 8-isoprostane を測定した。 Diffuse cutaneous SSc (dSSc), limited cutaneous SSc (ISSc) 患者における血清中 8-isoprostane 值は健常人と比 較して 75 倍もの高値で有意に上昇していた（図 8).一方, dSSc 患者と ISSc 患者の間においては有 意な差は認められなかった。驚くべきことに $99 \%$ の SSc 患者の 8-isoprostane 值は健常人の平均+ 3SD 值よりも高值であった。このように，ほとん どの SSc 患者が健常人よりも高值を示したため, 8-isoprostane 值で SSc 患者を健常人と区別するこ とが可能ではないかと思われた。

次に SSc における血清中 8-isoprostane 值と臨床 所見との相関の検討を行った. 初診時における血清
中 8-isoprostanet 值と臨床所見との相関では, \% VC $(\mathrm{r}=-0.42, \mathrm{p}<0.01)$, \%DLco $(\mathrm{r}=-0.0049, \mathrm{p}$ $<0.01)$ のように呼吸機能と負の相関が認められた (図 9).また, 腎血管抵抗をカラードップラー法に て評価した pulsatility index（PI） 值と血清中 8isoprostane 值を比較すると, 正の相関が有意に認 められた $(\mathrm{r}=0.53, \mathrm{p}<0.01)$. このことより，血管 病変との相関が示唆された. しかしながら，8-isorprostane 值と皮膚潰瘍との相関などは確認できなか つた. また，血清中の $\operatorname{IgG}$ 值 $(\mathrm{r}=0.43, \mathrm{p}<0.001)$, $\operatorname{IgA}$ 值 $(\mathrm{r}=0.44, \mathrm{p}<0.001)$ と正の相関を示し, 抗 ガラクトース欠損 $\operatorname{IgG}$ 抗体 (CARF) 值とも正の 相関を示した $(\mathrm{r}=0.60, \mathrm{p}<0.001)$.これは, 上昇 している 8-isoprostane 值が何らかの免疫異常に関 与している可能性を示唆するものであると考えられ た.

この研究において血清中 8-isoprostane 值は腎血

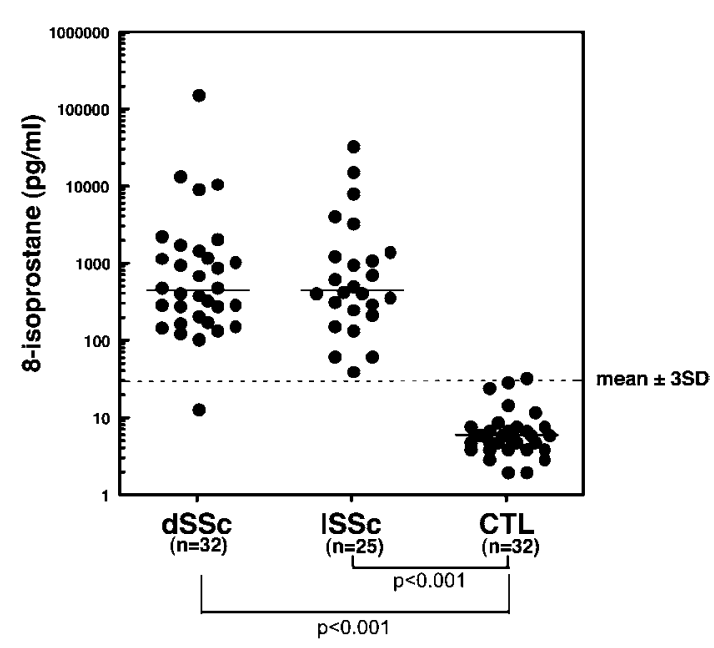

図 8 全身性強皮症 ( $\mathrm{SSc}$ ) 血清中の 8-isoprostane 值 Diffuse cutaneous systemic sclesosis (dSSc), limited cutaneous systemic sclerosis (dSSc) 患者血清中には健常人（CTL） と比較して有意に高值な 8-isoprostane を認める
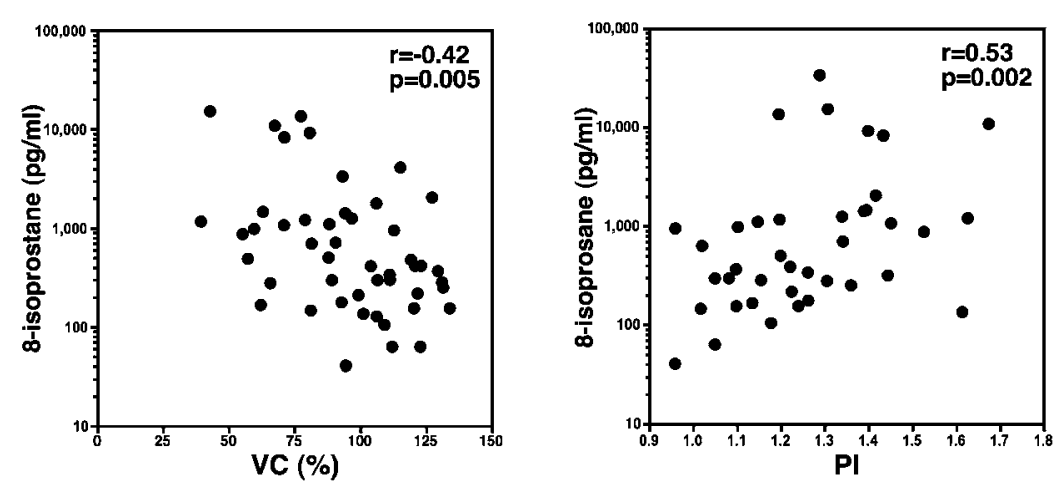

図 9 全身性強皮症（SSc）患者血清中 8-isoprostane 值と臨床検査所見との相関 呼吸機能検査で\% VC と負の相関を, 腎血管抵抗を pulsatility index (PI) 值で評価すると正の相関をいずれも有意に認める 
管障害と相関すると示されたが，血管内皮細胞の障 害は SSc において中心的な役割を果たすと考えら れている，その最も特徵的なものは血管の攣縮によ って引き起こされる手指のレイノー症状であるが, レイノー症状は手指のみならず，冠動脈や腎臓にお いても発生すると報告されている ${ }^{48)}$ 。そしてレイ ノ一症状による虚血再潅流が活性酸素の発生を引き 起こし，血管内皮細胞の障害を起こすことが示され ている ${ }^{42,49)}$ 。また，8-isoprostane 自体が血管収縮 作用を持つために，血小板凝集を引き起こし，血管 内皮への単球の接着を促し, 血管閉塞, 炎症, さら に血管の攣縮を引き起こす可能性が指摘されてい る。このように過剩な酸化ストレスが SSc の血管 障害に重要な役割を果たしていることが示唆された.

\section{SSc における抗 MsrA 自己抗体}

次に我々は，SSc における過剩な酸化ストレスの 原因として前述した抗酸化修復酵素 MsrA に対す る自己抗体の存在を考え, SSc 患者血清中の抗 MsrA 抗体の測定を ELISA 法を用いて relative OD での検討で行った（投稿準備中）。SSc 患者血清中 (mean \pm SEM, $0.70 \pm 0.04)$ には健常人（0.52 $0.03, \mathrm{p}<0.01 ）$ と比較して有意に高值の抗 MsrA 抗 体が存在した。一方, 病型間での比較では, dSSc 患者血清中と ISSc 患者血清中の抗 MsrA 自己抗体 に明らかな差は認められなかった。

さらに血清中抗 MsrA 自己抗体と臨床症状 - 検 查所見との相関を検討した. 初診時における血清中 抗 MsrA 自己抗体と臨床所見との相関では，\% VC $(\mathrm{r}=-0.38, \mathrm{p}<0.01), \% \mathrm{DLco}(\mathrm{r}=-0.26, \mathrm{p}<0.05)$ のように呼吸機能と負の相関が認められた。 また, 腎血管抵抗をPI 值で評価したところ正の相関が認 められた $(\mathrm{r}=0.31, \mathrm{p}<0.05)$. 以上のことより, SSc 患者血清中の抗 MsrA 自己抗体の存在は, 血管 病変との相関が示唆された。 また, SSc 患者血清中 の 8-isoprostane 值とは特に強い正の相関 $(\mathrm{r}=$ $0.52, \mathrm{p}<0.001 ）$ が確認できた.

以上のことより, SSc 患者血清中の抗 MsrA 抗体 の存在は, 8-isoprostane 值と強い相関が認められ たことからもわかるように, SSc 患者における酸化 ストレスの蓄積に重要な役割を果たしていると考え られ，その酸化ストレスは血管病変と特に関係が深 いと考えられた。

\section{VIII. おわりに}

ここまで述べたように酸化ストレスは紫外線曝露 による光老化のみならず, 皮膚硬化を主体とし血管 障害が疾患の形成に重要な役割を果たしている SSc の病勢・病態にも深く関与していることが明らかと なりつつある. 今後, 酸化ストレスの研究を進める ことにより光老化を軽減する薬剤や SSc の新規治 療が確立されることが期待される.

\section{文献}

1) Rabe JH, Mamelak AJ, McElgunn PJ, Morison WL, Sauder DN. : Photoaging : mechanisms and repair. J Am Acad Dermatol 55(1) : 1-19, 2006.

2) Lavker RM, Zheng PS, Dong G. : Morphology of aged skin. Clin Geriatr Med 5(1) : 53-67, 1989.

3) El-Domyati M, Attia S, Saleh F, Brown D, Birk DE, Gasparro F, et al. : Intrinsic aging vs. photoaging : a comparative histopathological, immunohistochemical, and ultrastructural study of skin. Exp Dermatol 11(5) : 398-405, 2002.

4) Kligman LH. : Photoaging. Manifestations, prevention, and treatment. Clin Geriatr Med 5(1) : 235-251, 1989.

5) Kawaguchi $Y$, Tanaka H, Okada T, Konishi H, Takahashi $\mathbf{M}$, Ito $\mathbf{M}$, et al. : The effects of ultraviolet $\mathrm{A}$ and reactive oxygen species on the mRNA expression of $72-\mathrm{kDa}$ type IV collagenase and its tissue inhibitor in cultured human dermal fibroblasts. Arch Dermatol Res 288 (1) : 39-44, 1996.

6) Oh JH, Kim A, Park JM, Kim SH, Chung AS. : Ultraviolet B-induced matrix metalloproteinase -1 and -3 secretions are mediated via PTEN/Akt pathway in human dermal fibroblasts. J Cell Physiol 209(3) : 775-785, 2006.

7) Onoue S, Kobayashi T, Takemoto Y, Sasaki I, Shinkai H. Induction of matrix metalloproteinase- 9 secretion from human keratinocytes in culture by ultraviolet B irradiation. $J$ Dermatol Sci 33(2) : 105-111, 2003.

8) Fisher GJ, Choi HC, Bata-Csorgo Z, Shao Y, Datta $S$, Wang ZQ, et al. : Ultraviolet irradiation increases matrix metalloproteinase- 8 protein in human skin in vivo. $J$ Invest Dermatol 
117 (2) : 219-226, 2001.

9) Bernstein EF, Brown DB, Schwartz MD, Kaidbey K, Ksenzenko SM. : The polyhydroxy acid gluconolactone protects against ultraviolet radiation in an in vitro model of cutaneous photoaging. Dermatol Surg 30 (2 Pt 1) : 189-195; discussion 196, 2004.

10) Kulms D, Zeise E, Poppelmann B, Schwarz T. : DNA damage, death receptor activation and reactive oxygen species contribute to ultraviolet radiation-induced apoptosis in an essential and independent way. Oncogene 21(38) : 58445851, 2002.

11) Cadet J, Douki T, Pouget JP, Ravanat JL. : Singlet oxygen DNA damage products : formation and measurement. Methods Enzymol 319 : 143-153, 2000.

12) Berlett BS, Stadtman ER. : Protein oxidation in aging, disease, and oxidative stress. $J$ Biol Chem 272 (33) : 20313-203166, 1997.

13) de Gruijl FR. : Photocarcinogenesis : UVA vs UVB. Methods Enzymol 319 : 359-366, 2000.

14) Fisher GJ, Kang S, Varani J, Bata-Csorgo Z, Wan Y, Datta S, et al. : Mechanisms of photoaging and chronological skin aging. Arch Dermatol 138(11) : 1462-1470, 2002.

15) Heck DE, Gerecke DR, Vetrano AM, Laskin JD. : Solar ultraviolet radiation as a trigger of cell signal transduction. Toxicol Appl Pharmacol 195 (3) : 288-297, 2004.

16) Fisher GJ, Talwar HS, Lin J, Lin P, McPhillips F, Wang Z, et al. : Retinoic acid inhibits induction of $\mathrm{c}-$ Jun protein by ultraviolet radiation that occurs subsequent to activation of mitogen-activated protein kinase pathways in human skin in vivo. J Clin Invest 101(6): 1432-1440, 1998

17) Fisher GJ, Wang ZQ, Datta SC, Varani J, Kang S, Voorhees JJ. : Pathophysiology of premature skin aging induced by ultraviolet light. $N$ Engl J Med 337 (20) : 1419-1428, 1997.

18) Reelfs O, Tyrrell RM, Pourzand C. : Ultraviolet a radiation-induced immediate iron release is a key modulator of the activation of NF-kappaB in human skin fibroblasts. $J$ Invest Dermatol 122 (6) : 1440-7, 2004.

19) Kang S, Fisher GJ, Voorhees JJ. : Photoaging : pathogenesis, prevention, and treatment. Clin Geriatr Med 17(4) : 643-659, v-vi, 2001.

20) Thiele JJ, Schroeter C, Hsieh SN, Podda M, Packer L.: The antioxidant network of the stratum corneum. Curr Probl Dermatol 29 : 2642, 2001.

21) Hata TR, Scholz TA, Ermakov IV, McClane RW, Khachik F, Gellermann W, et al. : Non-invasive raman spectroscopic detection of carotenoids in human skin. $J$ Invest Dermatol 115 (3) : 441-448, 2000.

22) Leccia MT, Yaar M, Allen N, Gleason M, Gilchrest BA. : Solar simulated irradiation modulates gene expression and activity of antioxidant enzymes in cultured human dermal fibroblasts. Exp Dermatol 10(4) : 272-279, 2001.

23) Sander CS, Chang H, Salzmann S, Muller CS, Ekanayake-Mudiyanselage S, Elsner P, et al. : Photoaging is associated with protein oxidation in human skin in vivo. $J$ Invest Dermatol 118 (4) : 618-625, 2002.

24) Sharov VS, Schoneich C.: Diastereoselective protein methionine oxidation by reactive oxygen species and diastereoselective repair by methionine sulfoxide reductase. Free Radic Biol Med 29(10) : 986-994, 2000.

25) Weissbach H, Etienne F, Hoshi T, Heinemann $\mathrm{SH}$, Lowther WT, Matthews B, et al. : Peptide methionine sulfoxide reductase : structure, mechanism of action, and biological function. Arch Biochem Biophys 397 (2) : 172-178, 2002.

26) Kuschel L, Hansel A, Schonherr R, Weissbach H, Brot N, Hoshi T, et al. : Molecular cloning and functional expression of a human peptide methionine sulfoxide reductase (hMsrA). FEBS Lett 456 (1) : 17-21, 1999.

27) Vougier S, Mary J, Friguet B. : Subcellular localization of methionine sulphoxide reductase A (MsrA) : evidence for mitochondrial and cytosolic isoforms in rat liver cells. Biochem $J$ 373 (Pt 2) : 531-537, 2003.

28) Hansel A, Kuschel L, Hehl S, Lemke C, Agricola HJ, Hoshi T, et al. Mitochondrial targeting of the human peptide methionine sulfoxide reductase (MSRA), an enzyme involved in the repair of oxidized proteins. Faseb J 16(8) : 911-913, 2002.

29) Hoshi T, Heinemann S. : Regulation of cell function by methionine oxidation and reduction. J Physiol 531 (Pt 1) : 1-11, 2001.

30) Wizemann TM, Moskovitz J, Pearce BJ, Cundell D, Arvidson CG, So M, et al. Peptide methionine sulfoxide reductase contributes to the maintenance of adhesins in three major pathogens. Proc Natl Acad Sci U S A 93(15) : 
7985-7990, 1996.

31) Vogt W. Oxidation of methionyl residues in proteins : tools, targets, and reversal. Free Radic Biol Med 18(1) : 93-105, 1995.

32) Squier TC, Bigelow DJ. Protein oxidation and age-dependent alterations in calcium homeostasis. Front Biosci 5 : D504-D526, 2000.

33) Schallreuter KU, Elwary SM, Gibbons NC, Rokos H, Wood JM. : Activation/deactivation of acetylcholinesterase by $\mathrm{H} 2 \mathrm{O} 2$ : more evidence for oxidative stress in vitiligo. Biochem Biophys Res Commun 315(2) : 502-508, 2004.

34) Moskovitz J, Flescher E, Berlett BS, Azare J, Poston JM, Stadtman ER. : Overexpression of peptide-methionine sulfoxide reductase in Saccharomyces cerevisiae and human $\mathrm{T}$ cells provides them with high resistance to oxidative stress. Proc Natl Acad Sci U S A 95(24): 14071-14075, 1998.

35) Moskovitz J, Bar-Noy S, Williams WM, Requena J, Berlett BS, Stadtman ER. : Methionine sulfoxide reductase (MsrA) is a regulator of antioxidant defense and lifespan in mammals. Proc Natl Acad Sci U S A 98(23): 12920-12925, 2001.

36) Ruan H, Tang XD, Chen ML, Joiner ML, Sun $\mathrm{G}$, Brot N, et al. : High-quality life extension by the enzyme peptide methionine sulfoxide reductase. Proc Natl Acad Sci U S A 99(5) : 27482753, 2002.

37) Chang H, Oehrl W, Elsner P, Thiele JJ. : The role of $\mathrm{H} 2 \mathrm{O} 2$ as a mediator of UVB-induced apoptosis in keratinocytes. Free Radic Res $37(6): 655-663,2003$.

38) Ogawa F, Sander CS, Hansel A, Oehrl W, Kasperczyk H, Elsner P, et al. : The repair enzyme peptide methionine-S-sulfoxide reductase is expressed in human epidermis and upregulated by UVA radiation. $J$ Invest Dermatol 126 (5) : 1128-1134, 2006.

39) Herrick AL, Rieley F, Schofield D, Hollis S, Braganza JM, Jayson MI. : Micronutrient antioxidant status in patients with primary Raynaud's phenomenon and systemic sclerosis. $J$ Rheumatol 21 (8) : 1477-1483, 1994.

40) Matucci Cerinic M, Kahaleh MB. : Beauty and the beast. The nitric oxide paradox in systemic sclerosis. Rheumatology (Oxford) 41 (8) : 843-
847, 2002.

41) Ignarro LJ. : Endothelium-derived nitric oxide : actions and properties. Faseb $J \mathbf{3}(1)$ : 31-36, 1989.

42) Butler AR, Flitney FW, Williams DL. : NO, nitrosonium ions, nitroxide ions, nitrosothiols and iron-nitrosyls in biology : a chemist's perspective. Trends Pharmacol Sci 16(1) : 18-22, 1995.

43) Morrow JD, Roberts LJ, 2nd. The isoprostanes. Current knowledge and directions for future research. Biochem Pharmacol 51(1) : 1-9, 1996.

44) Morrow JD, Frei B, Longmire AW, Gaziano JM, Lynch SM, Shyr Y, et al. : Increase in circulating products of lipid peroxidation (F2isoprostanes) in smokers. Smoking as a cause of oxidative damage. $N$ Engl J Med 332 (18) : 1198-1203, 1995.

45) Iuliano L, Pratico D, Greco C, Mangieri E, Scibilia G, FitzGerald GA, et al. Angioplasty increases coronary sinus F2-isoprostane formation : evidence for in vivo oxidative stress during PTCA. J Am Coll Cardiol 37(1) : 76-80, 2001.

46) Montuschi P, Kharitonov SA, Ciabattoni G, Corradi M, van Rensen L, Geddes DM, et al. : Exhaled 8-isoprostane as a new non-invasive biomarker of oxidative stress in cystic fibrosis. Thorax 55(3): 205-209, 2000.

47) Ogawa F, Shimizu K, Muroi E, Hara T, Hasegawa M, Takehara K, et al. : Serum levels of 8-isoprostane, a marker of oxidative stress, are elevated in patients with systemic sclerosis. Rheumatology (Oxford) $\mathbf{4 5 ( 7 ) : 8 1 5 - 8 1 8 ,}$ 2006.

48) Cannon PJ, Hassar M, Case DB, Casarella W J, Sommers SC, LeRoy EC. : The relationship of hypertension and renal failure in scleroderma (progressive systemic sclerosis) to structural and functional abnormalities of the renal cortical circulation. Medicine (Baltimore) 53(1): 1-46, 1974.

49) Suematsu M, Wakabayashi $Y$, Ishimura $Y$. : Gaseous monoxides : a new class of microvascular regulator in the liver. Cardiovasc Res $32(4)$ : 679-686, 1996. 